\title{
The long-term viability of US wine grape vineyards: assessing vineyard labour costs for future technology development
}

\section{Dean A. McCorkle*, Rebekka M. Dudensing and Dan D. Hanselka}

Department of Agricultural Economics, Texas A\&M AgriLife Extension Service, The Texas A\&M University System, 2124 TAMU, College Station, TX, USA

Email: d-mccorkle@tamu.edu

Email: rmdudensing@tamu.edu

Email: danhanselka@tamu.edu

*Corresponding author

\section{Ed W. Hellman}

Department of Horticultural Sciences,

Texas A\&M AgriLife Extension Service,

The Texas A\&M University System,

1102 E. FM 1294, Lubbock, TX 79403, USA

Email: ewhellman@ag.tamu.edu

\begin{abstract}
The motivation for this study centres on the labour-and cost-intensive nature of wine grape production and the potential opportunities for robotic technology. The objectives of this study are to develop cost of production budgets for five representative wine grape vineyards in four US states, assess the economic viability of wine grape production under current operating conditions, evaluate labour costs by production task, and identify common production challenges and tasks that could be augmented with robotic technology development. Investigators have worked with grower panels to develop a production budget for representative vineyards in four states, and to gather input on production tasks that the growers and technology developers feel would be most suitable for robotic technology. A stochastic simulation model was developed to assess baseline pro-forma financial statements for each vineyard size. Combined, the results help in exploring opportunities to strengthen vineyard profitability and competitiveness using robotics.

Keywords: wine grapes; robotic; technology; stochastic; Monte Carlo; simulation; labour; empirical distribution; financial statements; precision mechanisation.

Reference to this paper should be made as follows: McCorkle, D.A., Dudensing, R.M., Hanselka, D.D. and Hellman, E.W. (2019) 'The long-term viability of US wine grape vineyards: assessing vineyard labour costs for future technology development', Int. J. Entrepreneurship and Small Business, Vol. 36, No. 3, pp.308-334.
\end{abstract}


Biographical notes: Dean A. McCorkle is an Extension Program Specialist-Economic Accountability with the Texas A\&M AgriLife Extension Service, Department of Agricultural Economics, The Texas A\&M University System.

Rebekka M. Dudensing is Associate Professor and Extension Economist in Community Economic Development with the Texas A\&M AgriLife Extension Service, Department of Agricultural Economics, The Texas A\&M University System.

Dan D. Hanselka is an Extension Associate with the Texas A\&M AgriLife Extension Service, Department of Agricultural Economics, The Texas A\&M University System.

Ed W. Hellman is Professor and Extension Viticulturist with the Texas A\&M AgriLife Extension Service, Department of Horticultural Sciences, The Texas A\&M University System. He also holds a joint appointment as a Professor of Viticulture in the Department of Plant and Soil Science at Texas Tech University.

This paper is a revised and expanded version of a paper entitled 'Economics of wine grape production practices and the potential for robotic technology in selected growing areas of the US' presented at the 1st International Workshop on Innovations in the Wine Industry, Montpellier, France, 21-22 January 2016.

\section{Objectives}

The motivation for this study centres on the labour- and cost-intensive nature of wine grape production and the potential opportunities for robotic technology to augment those production tasks that are manual labour-intensive. The objectives of this study are to:

1 develop cost of production budgets for five representative wine grape vineyards in four USA states

2 assess the economic viability of wine grape production under current operating conditions

3 evaluate labour costs by production task

4 identify common production challenges and tasks that could be augmented with robotic technology development.

\section{Introduction}

In 2015, the USA produced an estimated 4.2 million tons of wine grapes. Wine grape acreage in the leading wine grape-producing states has increased from an estimated 521,000 acres in 2005 to 668,000 in 2014 , an increase of $28 \%$. There are approximately 25,000 wine grape vineyards in the USA (The National Association of American Wineries, 2014). California led the USA in wine grape production with 3.7 million tons produced on 560,000 acres. Washington was the second leading state with 230,000 
million tons on 48,000 acres, followed by Oregon with 65,000 tons (19,000 acres), New York with 143,000 tons, and Texas at 6th with 11,400 tons on 3,800 acres (NASS, 2015).

Grapes are among the most intensively managed fruit crops, requiring a great deal of manual labour to complete many production tasks including vine training, pruning, canopy management, and harvest. For example, labour hour requirements for wine grape production in the USA can range from 80 to 250 hours per acre, depending on the production system, harvest method used, and geographic location. For comparison, established blueberry production (hand harvested) in Oregon uses approximately 115 labour hours per acre while strawberry production in California uses about 180 hours per acre (machine-aided harvest) (Julian et al., 2011; Daugovish et al., 2011). Corn in Iowa and wheat in Texas can be produced with only 1 to 3 hours of labour per acre because the production process is fully mechanised (Plastina et al., 2016; Smith, 2015). Scarcity of skilled labour has been identified as an increasing challenge for the grape industry and has constrained continued expansion (MKF Research, 2007). A reduction in the availability of skilled labour generally leads to production quantity and quality issues, higher production costs, and decreased competitiveness in global markets. With a push for stricter border reform in the USA, there is cause for vineyards to be concerned about skilled labour availability and rising production and harvesting costs.

Machines have been developed to reduce most of the previous season's growth, remove leaves, position shoots, and thin fruit. However, these machines do not perform any of these tasks with the selectivity that many premium wine grape producers require.

Robotic technology has made significant contributions over the last decade and offers the potential to duplicate the efficacy of skilled human labour for vineyard tasks requiring selective activity. Today's industrial robots have dexterity, strength, reliability, speed and precision that is unparalleled by human workers. Wine grape production is primed for robotic technology as it faces a variety of production and labour issues that could affect long-term (LT) competitiveness. Mechanisation will be a key factor for achieving vineyard efficiencies within the production process, as robotics can potentially allow for selective pruning, thinning, training of vines and canopy, and crop estimation.

\subsection{Data and methods}

A representative farm panel process is a commonly used method for collecting farm-level data for research. For example, the Agricultural and Food Policy Centre (https://www.afpc.tamu.edu) at Texas A\&M University maintains a database of agricultural operations representing major production regions of the USA that is used for farm policy research (afpc.tamu.edu). And, Menghi et al. (2011) used a representative wine grape vineyard panel process to assess farmers' costs of compliance with EU legislation.

Using a grower panel process, this project includes the development of five representative wine grape vineyard budgets in the following four states: Washington (1), New York (1), Oregon (1), and Texas (2). The panels consist of three to five wine grape growers from a major production region within each state. Using a consensus building process, each panel provided 2015 budget information for the size of the vineyard, wine grape variety produced, cost of production, fixed costs, budgeted yield, yield distribution, budgeted price and price distribution, equipment compliment and replacement strategy, other assets, and loan terms and balances. Labour costs for various production tasks are of particular interest. The panels also provided input on the production tasks that they feel 
would be the most useful in terms of new technology being developed. A follow-up web conference meeting was also held to allow the panels to review the budget, validate the financial statements, and recommend further clarifications regarding production tasks and the potential for new technology. Using a representative vineyard panel process has several advantages such as it allows for a face-to-face conversation with the panel members to obtain their expert opinion on the data that is most representative of the geographic area being studied. However, a limitation of this approach is that the data does not represent a random sample and therefore conclusions cannot be made across the broader population.

Table 1 Representative vineyards production and financial information

\begin{tabular}{|c|c|c|c|c|c|}
\hline & $T X 50 a c$. & $T X 100 a c$. & $W A$ & OR & $N Y$ \\
\hline Variety & $\begin{array}{l}\text { Cabernet } \\
\text { sauvignon }\end{array}$ & $\begin{array}{l}\text { Cabernet } \\
\text { sauvignon }\end{array}$ & $\begin{array}{l}\text { Cabernet } \\
\text { sauvignon }\end{array}$ & Pinot noir & Riesling \\
\hline $\begin{array}{l}\text { Trellis system } \\
\text { type* }\end{array}$ & VSP & VSP & VSP & VSP & VSP \\
\hline $\begin{array}{l}\text { Pre-pruning } \\
\text { method }\end{array}$ & Mechanical & Mechanical & Mechanical & & \\
\hline $\begin{array}{l}\text { Finish pruning } \\
\text { method }\end{array}$ & Spur prune & Spur prune & Spur prune & Cane prune & Cane prune \\
\hline Harvest method & $\begin{array}{l}\text { Custom } \\
\text { machine }\end{array}$ & $\begin{array}{l}\text { Machine } \\
\text { (owned) }\end{array}$ & $\begin{array}{l}\text { Custom } \\
\text { machine }\end{array}$ & Hand harvest & $\begin{array}{l}\text { Custom } \\
\text { machine }\end{array}$ \\
\hline Acres & 50 & 100 & 250 & 10 & 50 \\
\hline $\begin{array}{l}\text { Deterministic } \\
\text { yield (tons/ac.) }\end{array}$ & 6.0 & 4.0 & 4.0 & 3.0 & 4.5 \\
\hline $\begin{array}{l}\text { Deterministic } \\
\text { price (USD/ton) }\end{array}$ & $\$ 1,600$ & $\$ 1,600$ & $\$ 1,600$ & $\$ 2,600$ & $\$ 1,550$ \\
\hline Crop insurance & MPCI 65/100 & MPCI 65/100 & CAT 50/55 & N/A & MPCI 65/100 \\
\hline Beginning assets & $\$ 758,500$ & $\$ 1,403,500$ & $\$ 3,691,900$ & $\$ 413,700$ & $\$ 794,000$ \\
\hline Long-term debt & $\$ 267,500$ & $\$ 535,000$ & $\$ 1,150,000$ & $\$ 165,000$ & $\$ 293,200$ \\
\hline Equipment debt & $\$ 102,200$ & $\$ 203,200$ & $\$ 447,000$ & $\$ 74,000$ & $\$ 117,700$ \\
\hline $\begin{array}{l}\text { Establishment } \\
\text { cost debt }\end{array}$ & $\$ 194,900$ & $\$ 389,800$ & $\$ 1,125,000$ & $\$ 75,000$ & $\$ 300,000$ \\
\hline $\begin{array}{l}\text { Owner operator } \\
\text { annual cash } \\
\text { withdrawal }\end{array}$ & $\$ 70,000$ & $\$ 70,000$ & $\$ 130,000$ & $\$ 0$ & $\$ 35,000$ \\
\hline
\end{tabular}

Note: ${ }^{*} \mathrm{VSP}=$ vertically shoot positioning system.

A description of selected production and financial characteristics for each representative vineyard can be found in Table 1. Regarding deterministic yields, it is worth noting that the two Texas representative vineyards each had their own panel of growers. The growers on the 50 acre vineyard panel had a more aggressive production philosophy and use more intensive practices which are the reasons this vineyard has a higher deterministic yield than the 100 acre Texas vineyard (6 tons compared to 4 tons). For all representative vineyards, land is owned and is financed with the beginning balance reflected in the LT debt balance in Table 1. The land payment schedule has 20 years remaining with an interest rate of 5.5\%. Establishment cost loans have 15 years remaining and are financed 
at 5.5\%. The equipment loan balance has five years remaining at a 5\% interest rate. Each vineyard takes an owner-operator cash withdrawal from the business as specified in Table 1 , except for Oregon because this vineyard was unable to generate adequate cash to support a cash withdrawal.

A summary of the production cost budget for the representative wine grape vineyards is presented in Table 2, which includes subtotals for the various production tasks by budget category. Oregon vineyards, which produce wine grapes for premium wines, face the highest costs due to substantial reliance on manual labour rather than automation. For example, canopy management is almost four times more expensive per acre in Oregon than in other states. As the smallest vineyard, Oregon may also lose economies of scale. With 250 acres, the Washington representative vineyard is the largest, and it had the lowest per acre costs. Total per acre costs for the Texas and New York vineyards were similar, although differences in regional production result in different allocations of spending across categories.

Table 2 Production budgets for the USA representative wine grapes vineyards (\$/acre)

\begin{tabular}{lccccc}
\hline Vineyard practice & TX 50 ac. & TX 100 ac & $W A$ & OR & $N Y$ \\
\hline Number of acres & 50 & 100 & 250 & 10 & 50 \\
Budgeted yield (Tons/ac.) & 6.00 & 4.00 & 4.00 & 3.00 & 4.50 \\
Budgeted price (\$/ton) & $\$ 1,600$ & $\$ 1,600$ & $\$ 1,600$ & $\$ 2,600$ & $\$ 1,550$ \\
\hline Total gross receipts & $\$ 9,688$ & $\$ 6,488$ & $\$ 6,400$ & $\$ 7,800$ & $\$ 6,975$ \\
Operating costs & & & & & \\
Floor management - Dormant season & $\$ 38$ & $\$ 38$ & $\$ 92$ & $\$ 0$ & $\$ 180$ \\
Pruning & $\$ 1,268$ & $\$ 1,209$ & $\$ 270$ & $\$ 942$ & $\$ 1,064$ \\
canopy management & $\$ 529$ & $\$ 529$ & $\$ 318$ & $\$ 2,015$ & $\$ 660$ \\
Floor management - Growing season & $\$ 78$ & $\$ 78$ & $\$ 92$ & $\$ 252$ & $\$ 88$ \\
Weed management - Vine row & $\$ 479$ & $\$ 293$ & $\$ 401$ & $\$ 70$ & $\$ 270$ \\
Irrigation & $\$ 50$ & $\$ 50$ & $\$ 260$ & $\$ 86$ & $\$ 0$ \\
Chemical/Pest control & $\$ 279$ & $\$ 225$ & $\$ 379$ & $\$ 604$ & $\$ 800$ \\
Harvest & $\$ 892$ & $\$ 630$ & $\$ 337$ & $\$ 1,051$ & $\$ 458$ \\
Miscellaneous costs & $\$ 188$ & $\$ 188$ & $\$ 148$ & $\$ 176$ & $\$ 117$ \\
Cash overhead costs & $\$ 837$ & $\$ 805$ & $\$ 768$ & $\$ 496$ & $\$ 660$ \\
\hline Total cash costs & $\$ 4,637$ & $\$ 4,045$ & $\$ 3,065$ & $\$ 5,692$ & $\$ 4,296$ \\
\hline Non-cash overhead costs & $\$ 2,346$ & $\$ 2,342$ & $\$ 2,630$ & $\$ 5,692$ & $\$ 2,012$ \\
Total costs & $\$ 6,983$ & $\$ 6,387$ & $\$ 5,696$ & $\$ 11,384$ & $\$ 6,308$ \\
Net returns above cash costs & $\$ 5,050$ & $\$ 2,443$ & $\$ 3,335$ & $\$ 2,108$ & $\$ 2,679$ \\
Net returns above total costs & $\$ 2,705$ & $\$ 100$ & $\$ 704$ & $-\$ 3,584$ & $\$ 667$ \\
\hline
\end{tabular}

\section{Economic viability of wine grape production}

To evaluate the economic viability of each representative vineyard using current production methods and technology, data from the representative budgets were used to 
develop a projected income statement, cash flow statement, and balance sheet to estimate financial outcomes over a ten-year projection period (2015-2024). These baseline scenarios reflect the representative vineyards' current production and operating practices, projected over a ten-year planning horizon. Long-range, annual projections of inflation rate indices (Appendix Table A1) for input prices, labour costs, equipment prices, and interest rates by the Food and Agricultural Policy Research Institute (FAPRI) at the University of Missouri form the basis for vineyard expense projections (FAPRI, 2015).

\subsection{Stochastic simulation}

While financial statements for a business, when presented in a deterministic mode, can provide useful information about a business or investment, this type of analysis is limited. Deterministic investment analyses that ignore risk provide only a point estimate of potential financial outcomes instead of estimates for probability distributions that show the chances of success or failure (Pouliquen, 1970; Reutlinger, 1970; Hardaker et al., 2004).

Monte Carlo simulation offers business analysts and investors an economical means of conducting risk-based economic feasibility studies for new investments and a non-destructive means of stress testing existing business under risk (Richardson et al., 2007). Stochastic models are used to generate a large sample of economic outcomes that are dependent on a defined set of risky variables. A unique feature of stochastic simulation models is that there is an explicit recognition that the independent variables have some probability distribution around their means (Paggi et al., 2007).

Richardson (2006) outlines the methodology for developing a simulation model for a production oriented business. The steps begin with defining the probability distributions for all risky variables, simulating the variables, and validating the simulation results. The stochastic values from the probability distribution are used in accounting equations to calculate production, gross revenue, expenses, cash flows, and balance sheet values for the business. Financial statement variables become stochastic by sampling stochastic values from the probability distribution. Finally, the stochastic model is simulated many times (500 iterations for example) using random values for the stochastic variables. The 500 samples provide information used to estimate empirical probability distributions for key output variables (KOVs) such as net cash income, net income, and ending cash reserves. This allows for evaluating the probability of success for a business. The stochastic model can also be used to analyse alternative management plans and/or investment strategies.

\section{Monte Carlo simulation model for wine grape production}

A stochastic simulation model was developed to evaluate the viability of the five representative wine grape vineyards. The model consists of equations necessary to develop a projected income statement, cash flow statement, and a balance sheet. The financial statements are annual for a ten year projection period, 2015-2024. The model includes two risky variables - yield and price - and was developed using Simetar(C) (2011), a simulation add-in program designed for risk analysis in Microsoft ${ }^{\circledR}$ Excel. 


\subsection{Stochastic variables}

Stochastic variables in a Monte Carlo simulation model are variables the decision maker is unable to forecast with certainty. Such variables have two components: the deterministic component, which can be forecasted with certainty, and the stochastic component, which cannot be forecasted with certainty (Richardson et al., 2007). To simulate stochastic yields and prices, a multivariate probability distribution was developed for each representative vineyard based on panel input. Similar simulation models have been developed and used by Falconer and Richardson (2013), Outlaw et al. (2007), and Richardson and Mapp (1976) to analyse proposed business and policy changes.

Stochastic variables in the wine grape model used in this study include annual prices for grapes, and annual yields (tons/acre). State-wide, historical annual grape prices from 2005-2014 were provided by the panels. The sources of these data are state wine grape grower associations, or the National Agricultural Statistics Service of the US of the Department of Agriculture's (USDA). Normally, state-wide average price data would not be representative of the price risk that an individual grower faces. However, after reviewing the price data, each grower panel confirmed that historical state-wide average price data is a good approximation of the historical price risk they have faced, with the exception of Washington. Due to the three year contractual arrangements for wine grapes in Washington, and the growers' past experience, the panel indicated that price risk is not a significant concern for growers. As a result, price in the Washington model is not treated as a stochastic variable. Also, per the panel's input, the deterministic price is increased by $3 \%$ every third year to account for typical price adjustments in the three-year contracts. For Oregon, the deterministic price is increased by $3 \%$ each year. For Texas, and New York, the deterministic price is the same each year.

Due to the lack of quality data for historical yields, each panel developed a yield distribution to represent the yield risk for their representative vineyard. Each distribution is comprised of yields (tons) per acre and the frequency of each yield where the frequency sums to ten. The price and yield distributions were used to estimate the parameters for the empirical distribution, and the stochastic variables were simulated using an empirical distribution.

The equations for the simulation model can be found in Appendix. Equations (A1) and (A2) in Appendix provide detail about how the random variables were simulated. Equations (A1) was simulated as an empirical distribution, defined by the fractional deviations from trend $\left(S_{i}\right)$, and cumulative probabilities $\left(F\left(S_{i}\right)\right.$ ). Equation (A2) was simulated as an empirical distribution, defined by the fractional deviations from the mean $\left(R_{i}\right)$, and cumulative probabilities $\left(F\left(R_{i}\right)\right)$.

Projected means for the stochastic variables over the 2015-2024 study period were the baseline price and yield for year one provided by the panel of wine grape producers for each given state. The baseline deterministic price and yield were held constant throughout the ten-year planning horizon for New York and both Texas representative vineyards, based on panel input. For Washington, the panel advised to increase the price by $3 \%$ every third year to take into account the three-year contract arrangements that are common there. For Oregon, the deterministic price is increased by 3\% each year. The stochastic variables were simulated for 500 iterations. 


\subsection{Projected financial statements}

Equations from the projected financial statements for a deterministic economic model comprise the majority of the equations for the Monte Carlo simulation model. The two stochastic variables in equations (A1) to (A2) were used as exogenous variables in the pro forma financial statement equations to incorporate risk into the model (Richardson et al., 2007). The equations for income and expenses in the income statement, cash flow statement, and the balance sheet are summarised in Appendix as equations (A3) to (A58).

\subsection{Income}

Annual wine grape sales (A3) were computed by multiplying the stochastic grape price by the stochastic yield and wine grape acres. Texas and New York both have multi-peril crop insurance with $65 \%$ yield coverage and $100 \%$ price coverage, while Washington has catastrophic (CAT) coverage with $50 \%$ yield coverage and $55 \%$ price coverage. Crop insurance indemnity payments (A4) were calculated when the stochastic wine grape yield is less than the guaranteed yield [yield coverage percent $\times$ average production history (APH) yield]. The difference is then multiplied by the established grape price, which is specific for the wine grape variety and county where the representative vineyard is located; and wine grape acres. Land rental income (A5), which only applies to the two Texas vineyards due to irrigation water constraints in the area, was the product of the number of acres and the rental charge per acre. ${ }^{1}$ Total income (A6) equals the sum of wine grape sales, crop insurance indemnity payments when applicable, and land rental income.

\subsection{Expenses}

All variable costs and cash overhead costs (A7) to (A31) were calculated using the base cost per acre provided by the panels, adjusted annually for the projected annual inflation rates (Appendix Table A1), and the number of acres.

Interest on the operating loan is based on the vineyards borrowing $100 \%$ of operating funds for one-half of the year. Operating loan interest (A32) was calculated using the annual interest rate, $50 \%$ of the year, and the number of acres. Operating interest costs also includes any interest on operating carryover debt incurred during the simulation. An annual intermediate loan equal to $50 \%$ of the total equipment assets was used for the analysis, and the intermediate loan payment and interest (A33) was calculated using the beginning equipment loan balance, interest rate, and five years remaining.

The beginning LT loan balance includes $75 \%$ of the land value, $50 \%$ of buildings value, and $50 \%$ of drip irrigation system value. LT loan payment and interest cost (A34) was derived using the LT beginning balance, interest rate, and 20 years remaining. The beginning vineyard establishment costs loan equals $30 \%$ of the total establishment costs, and the establishment loan payment and interest costs (A35) were calculated using interest rate, and 15 years remaining. Total interest cost (A36) is the sum of the interest costs for operating, intermediate, LT, and vineyard establishment cost loans.

Annual equipment depreciation (A37) was calculated using the total equipment costs and annual capital replacement, multiplied by the Modified Accelerated Cost Recovery System (MACRS) fractions for an asset with a seven-year life. Annual depreciation of the 
buildings (A38) was computed using the MACRS fractions for an asset with a 20-year life. Annual depreciation for the drip irrigation system (A39) was calculated using the MACRS fractions for an asset with a seven-year life. Annual depreciation for vineyard establishment costs (A40) was calculated using the MACRS fractions for an asset with a ten-year life. Total depreciation (A41) is the sum of the annual depreciation for equipment, buildings, drip irrigation system, and vineyard establishment costs.

Total expenses (A42) equal total variable costs plus total interest and depreciation. Net cash vineyard income (NCVI) (A43) was calculated as the total income minus total variable costs and interest. Net vineyard income (A44) was computed as NCVI minus depreciation.

\subsection{Cash flow statement}

The annual cash flows were calculated using equations (A45) to (A54). Total cash available (A45) equals NCVI (A43) plus any positive cash reserves from the previous year (A54). In the stochastic model, ending cash reserves can be positive or negative. Positive cash reserves are a cash inflow carried forward to the following year, while negative cash reserves are cash flow deficits that require carryover financing the next year (A49) (Richardson et al., 2007). Cash outflows in the cash flow statement (A53) are the sum of cash vineyard expenses, principal portions of scheduled loan payments, any operating loan carryover, owner operator management withdrawals, federal income taxes, and self-employment and social security taxes. Ending cash reserves (A54) equals total cash available minus total cash outflows. If ending cash reserves is negative, cash is borrowed on short-term operating loan and is reported on the balance sheet as short-term carryover debt. If ending cash is positive the following year, it is used to pay down the short-term carryover debt.

\subsection{Balance sheet}

The value of total assets (A55) was computed annually using the estimated land value, remaining market value of equipment, and ending cash reserves. The projected value of land is adjusted each year based on the projected annual inflation rate for land values (FAPRI, 2015). The market value of equipment declines at a rate equal to straight-line depreciation over the expected life, until it reaches its salvage value. Total liabilities (A56) equal the sum of remaining LT loan debt, intermediate loan debt, vineyard establishment costs loan debt, and any short-term loan debt. Nominal net worth (A57) was computed by subtracting total liabilities from total assets. To calculate real net worth (A58), nominal net worth was adjusted annually for inflation using an average inflation index based on projected inflation rates for farm inputs for by FAPRI (2015).

\section{Results}

Results for the stochastic simulation analysis are presented in Table 3 for the two Texas, Oregon, Washington, and New York representative vineyards. The results include the annual mean values from the simulations for 2015-2024 for yield, price, total cash receipts, NCVI, net vineyard income, ending cash reserves, short-term carryover debt, and real net worth. The mean total cash receipts vary from $\$ 89,442$ (Oregon) to 
\$1.6 million (Washington) due to the wide range in vineyard size while the coefficient of variation is similar for each representative vineyard, ranging from $21.5 \%$ (Washington) to $27.3 \%$ (TX $50 \mathrm{ac}$ ).

Table 3 Summary of stochastic results for representative US wine grape vineyards

\begin{tabular}{|c|c|c|c|c|c|}
\hline & $T X 50 a c$ & $T X 100 a c$ & $W A$ & OR & $N Y$ \\
\hline \multicolumn{6}{|l|}{ Yield } \\
\hline Mean & 6.0 & 4.0 & 4.0 & 3.0 & 4.5 \\
\hline Standard deviation & 1.9 & 1.3 & 0.9 & 0.7 & 1.1 \\
\hline $\begin{array}{l}\text { Coefficient of } \\
\text { variation (\%) }\end{array}$ & 31.9 & 31.9 & 21.3 & 23.2 & 24.3 \\
\hline Minimum & 1.8 & 1.2 & 2.5 & 2.0 & 1.7 \\
\hline Maximum & 9.0 & 6.0 & 5.5 & 4.0 & 5.9 \\
\hline \multicolumn{6}{|l|}{ Price } \\
\hline Mean & $\$ 1,601$ & $\$ 1,601$ & $\$ 1,600$ & $\$ 2,981$ & $\$ 1,550$ \\
\hline Standard deviation & $\$ 99$ & $\$ 99$ & $\$ 0$ & $\$ 300$ & $\$ 64$ \\
\hline $\begin{array}{l}\text { Coefficient of } \\
\text { variation }(\%)\end{array}$ & 6.16 & 6.16 & 0 & 10.05 & 4.11 \\
\hline Minimum & $\$ 1,434$ & $\$ 1,434$ & $\$ 1,600$ & $\$ 2,341$ & $\$ 1,429$ \\
\hline Maximum & $\$ 1,781$ & $\$ 1,781$ & $\$ 1,600$ & $\$ 3,783$ & $\$ 1,644$ \\
\hline \multicolumn{6}{|l|}{ Total cash receipts } \\
\hline Mean & $\$ 496,593$ & $\$ 664,830$ & $\$ 1,673,331$ & $\$ 89,442$ & $\$ 348,874$ \\
\hline Standard deviation & $\$ 135,363$ & $\$ 179,422$ & $\$ 360,002$ & $\$ 22,758$ & $\$ 85,864$ \\
\hline $\begin{array}{l}\text { Coefficient of } \\
\text { variation }(\%)\end{array}$ & 27.3 & 27.0 & 21.5 & 25.4 & 24.6 \\
\hline Minimum & $\$ 195,287$ & $\$ 283,322$ & $\$ 999,940$ & $\$ 46,818$ & $\$ 125,579$ \\
\hline Maximum & $\$ 801,912$ & $\$ 1,072,135$ & $\$ 2,404,064$ & $\$ 151,323$ & $\$ 486,728$ \\
\hline \multicolumn{6}{|l|}{ Net cash vineyard income } \\
\hline Mean & $\$ 200,977$ & $\$ 132,992$ & $\$ 653,783$ & $\$ 7,431$ & $\$ 78,744$ \\
\hline Standard deviation & $\$ 137,170$ & $\$ 185,388$ & $\$ 357,403$ & $\$ 21,763$ & $\$ 88,548$ \\
\hline $\begin{array}{l}\text { Coefficient of } \\
\text { variation }(\%)\end{array}$ & 68.3 & 139.4 & 54.7 & 292.9 & 112.5 \\
\hline Minimum & $-\$ 142,969$ & $-\$ 412,391$ & $-\$ 57,140$ & $-\$ 39,831$ & $-\$ 200,487$ \\
\hline Maximum & $\$ 537,580$ & $\$ 601,474$ & $\$ 1,312,013$ & $\$ 64,429$ & $\$ 244,723$ \\
\hline \multicolumn{6}{|l|}{ Net vineyard income } \\
\hline Mean & $\$ 137,888$ & $\$ 12,766$ & $\$ 367,742$ & $-\$ 19,757$ & $\$ 3,910$ \\
\hline Standard deviation & $\$ 137,421$ & $\$ 186,799$ & $\$ 396,217$ & $\$ 29,365$ & $\$ 89,244$ \\
\hline $\begin{array}{l}\text { Coefficient of } \\
\text { variation (\%) }\end{array}$ & 99.7 & $1,463.2$ & 107.7 & -148.6 & $2,282.3$ \\
\hline Minimum & $-\$ 198,758$ & $-\$ 434,202$ & $-\$ 467,126$ & $-\$ 77,881$ & $-\$ 260,156$ \\
\hline Maximum & $\$ 480,619$ & $\$ 478,925$ & $\$ 1,256,547$ & $\$ 56,984$ & $\$ 183,375$ \\
\hline
\end{tabular}


Table 3 Summary of stochastic results for representative US wine grape vineyards (continued)

\begin{tabular}{|c|c|c|c|c|c|}
\hline & $T X 50 a c$ & $T X 100 a c$ & $W A$ & $O R$ & $N Y$ \\
\hline \multicolumn{6}{|l|}{ Ending cash reserves } \\
\hline Mean & $\$ 320,892$ & $\$ 136,541$ & $\$ 1,374,858$ & $\$ 1,869$ & $\$ 83,438$ \\
\hline Standard deviation & $\$ 255,311$ & $\$ 198,959$ & $\$ 847,148$ & $\$ 8,654$ & $\$ 102,926$ \\
\hline $\begin{array}{l}\text { Coefficient of } \\
\text { variation }(\%)\end{array}$ & 79.6 & 145.7 & 61.6 & 463.1 & 123.4 \\
\hline Minimum & $\$ 0$ & $\$ 0$ & $\$ 0$ & $\$ 0$ & $\$ 0$ \\
\hline Maximum & $\$ 1,348,820$ & $\$ 1,307,475$ & $\$ 4,560,721$ & $\$ 127,498$ & $\$ 514,150$ \\
\hline \multicolumn{6}{|l|}{ Short-term carryover debt } \\
\hline Mean & $\$ 19,194$ & $\$ 202,768$ & $\$ 6,371$ & $\$ 77,386$ & $\$ 81,773$ \\
\hline Standard deviation & $\$ 74,621$ & $\$ 323,347$ & $\$ 45,897$ & $\$ 62,346$ & $\$ 157,455$ \\
\hline $\begin{array}{l}\text { Coefficient of } \\
\text { variation }(\%)\end{array}$ & 388.8 & 159.5 & 720.4 & 80.6 & 192.6 \\
\hline Minimum & $\$ 0$ & $\$ 0$ & $\$ 0$ & $\$ 0$ & $\$ 0$ \\
\hline Maximum & $\$ 1,299,484$ & $\$ 2,499,460$ & $\$ 939,068$ & $\$ 357,406$ & $\$ 1,546,834$ \\
\hline \multicolumn{6}{|l|}{ Real net worth } \\
\hline Mean & $\$ 461,676$ & $\$ 320,565$ & $\$ 2,159,180$ & $\$ 68,719$ & $\$ 166,205$ \\
\hline Standard deviation & $\$ 250,757$ & $\$ 368,796$ & $\$ 743,950$ & $\$ 50,198$ & $\$ 183,428$ \\
\hline $\begin{array}{l}\text { Coefficient of } \\
\text { variation }(\%)\end{array}$ & 54.3 & 115.0 & 34.5 & 73.0 & 110.4 \\
\hline Minimum & $-\$ 757,217$ & $-\$ 1,541,139$ & $\$ 167,482$ & $-\$ 135,487$ & $-\$ 993,001$ \\
\hline Maximum & $\$ 1,324,938$ & $\$ 1,480,928$ & $\$ 4,697,048$ & $\$ 245,756$ & $\$ 618,828$ \\
\hline
\end{tabular}

The mean results for the KOVs for each year are presented in Table 4. Mean total cash receipts for all representative vineyards are relatively stable each year except for Oregon and Washington. The Texas 50 acre vineyard has a higher mean net vineyard income than the Texas 100 acre vineyard. This is mostly attributable production as the 50 acre vineyard has a 6 ton per acre deterministic yield, compared to 4 tons for the 100 acre vineyard. In 8 of the ten years in the planning horizon, Oregon has a negative mean net vineyard income. Washington, the largest vineyard at 250 acres, has a mean net vineyard income of $\$ 367,742$ over the ten-year planning horizon. New York's mean net vineyard income is negative the first five years, turns positive the last five years, and has a ten-year average of $\$ 3,910$.

In terms of cash flow ability, all five representative vineyards have a positive mean ending cash reserves at the end of 2024. Washington has the highest at \$2.1 million while Oregon has the lowest at $\$ 1,869$. However, all the vineyards also show varying levels of mean short-term carryover debt at the end of 2024. The Texas 100 acre vineyard has the highest level of mean short-term carryover debt at the end of 2024 at $\$ 477,079$.

For real net worth, the Texas 50 acre vineyard shows the highest mean change in real net worth (from beginning of 2015 to the end of 2024) with a $116 \%$ increase. Due to profitability and cash flow problems, real net worth for the Oregon vineyard declines $18 \%$ over the ten-year planning period. 
Table 4 Mean stochastic KOVs of representative wine grape vineyards, 2015-2024

\begin{tabular}{|c|c|c|c|c|c|}
\hline & $T X 50 a c$. & $T X 100 a c$. & $W A$ & OR & $N Y$ \\
\hline \multicolumn{6}{|l|}{ Total cash receipts } \\
\hline 2015 & $\$ 494,030$ & $\$ 660,092$ & $\$ 1,600,063$ & $\$ 78,096$ & $\$ 348,767$ \\
\hline 2016 & $\$ 495,131$ & $\$ 661,553$ & $\$ 1,600,045$ & $\$ 80,328$ & $\$ 348,891$ \\
\hline 2017 & $\$ 495,289$ & $\$ 663,449$ & $\$ 1,648,025$ & $\$ 82,811$ & $\$ 348,813$ \\
\hline 2018 & $\$ 495,467$ & $\$ 664,181$ & $\$ 1,648,050$ & $\$ 85,293$ & $\$ 348,971$ \\
\hline 2019 & $\$ 496,737$ & $\$ 665,420$ & $\$ 1,648,010$ & $\$ 87,773$ & $\$ 348,898$ \\
\hline 2020 & $\$ 497,272$ & $\$ 664,349$ & $\$ 1,697,428$ & $\$ 90,380$ & $\$ 348,916$ \\
\hline 2021 & $\$ 496,174$ & $\$ 665,633$ & $\$ 1,697,453$ & $\$ 93,133$ & $\$ 348,984$ \\
\hline 2022 & $\$ 497,307$ & $\$ 667,026$ & $\$ 1,697,479$ & $\$ 95,981$ & $\$ 349,035$ \\
\hline 2023 & $\$ 499,213$ & $\$ 668,665$ & $\$ 1,748,341$ & $\$ 98,870$ & $\$ 348,709$ \\
\hline 2024 & $\$ 499,312$ & $\$ 667,928$ & $\$ 1,748,414$ & $\$ 101,755$ & $\$ 348,754$ \\
\hline 2015-2024 average & $\$ 496,593$ & $\$ 664,830$ & $\$ 1,673,331$ & $\$ 89,442$ & $\$ 348,874$ \\
\hline \multicolumn{6}{|c|}{ Net cash vineyard income } \\
\hline 2015 & $\$ 230,732$ & $\$ 192,859$ & $\$ 681,955$ & $\$ 4,701$ & $\$ 106,769$ \\
\hline 2016 & $\$ 226,085$ & $\$ 182,786$ & $\$ 665,296$ & $\$ 5,442$ & $\$ 101,950$ \\
\hline 2017 & $\$ 220,197$ & $\$ 172,422$ & $\$ 693,337$ & $\$ 6,229$ & $\$ 96,403$ \\
\hline 2018 & $\$ 213,867$ & $\$ 160,346$ & $\$ 671,653$ & $\$ 6,919$ & $\$ 90,865$ \\
\hline 2019 & $\$ 207,923$ & $\$ 147,470$ & $\$ 648,862$ & $\$ 7,530$ & $\$ 84,767$ \\
\hline 2020 & $\$ 200,388$ & $\$ 130,113$ & $\$ 671,739$ & $\$ 7,815$ & $\$ 77,808$ \\
\hline 2021 & $\$ 188,840$ & $\$ 111,798$ & $\$ 637,207$ & $\$ 8,549$ & $\$ 68,874$ \\
\hline 2022 & $\$ 180,410$ & $\$ 94,770$ & $\$ 612,626$ & $\$ 8,388$ & $\$ 60,717$ \\
\hline 2023 & $\$ 174,658$ & $\$ 78,807$ & $\$ 639,791$ & $\$ 9,177$ & $\$ 54,067$ \\
\hline 2024 & $\$ 166,667$ & $\$ 58,548$ & $\$ 615,366$ & $\$ 9,563$ & $\$ 45,217$ \\
\hline 2015-2024 average & $\$ 200,977$ & $\$ 132,992$ & $\$ 653,783$ & $\$ 7,431$ & $\$ 78,744$ \\
\hline \multicolumn{6}{|l|}{ Net vineyard income } \\
\hline 2015 & $\$ 120,192$ & $-\$ 27,881$ & $\$ 178,187$ & $-\$ 43,879$ & $-\$ 12,433$ \\
\hline 2016 & $\$ 115,600$ & $-\$ 37,843$ & $\$ 161,516$ & $-\$ 43,064$ & $-\$ 17,017$ \\
\hline 2017 & $\$ 109,878$ & $-\$ 47,876$ & $\$ 190,012$ & $-\$ 42,157$ & $-\$ 22,269$ \\
\hline 2018 & $\$ 103,586$ & $-\$ 59,874$ & $\$ 168,282$ & $-\$ 41,406$ & $-\$ 27,612$ \\
\hline 2019 & $\$ 140,509$ & $\$ 12,812$ & $\$ 318,702$ & $-\$ 22,275$ & $-\$ 3,599$ \\
\hline 2020 & $\$ 175,096$ & $\$ 80,747$ & $\$ 513,786$ & $-\$ 4,119$ & $\$ 19,330$ \\
\hline 2021 & $\$ 159,219$ & $\$ 57,495$ & $\$ 467,906$ & $-\$ 3,944$ & $\$ 8,083$ \\
\hline 2022 & $\$ 153,885$ & $\$ 55,351$ & $\$ 503,052$ & $-\$ 1,248$ & $\$ 20,784$ \\
\hline 2023 & $\$ 154,950$ & $\$ 57,997$ & $\$ 600,698$ & $\$ 2,400$ & $\$ 42,059$ \\
\hline 2024 & $\$ 145,962$ & $\$ 36,737$ & $\$ 575,282$ & $\$ 2,119$ & $\$ 31,777$ \\
\hline 2015-2024 average & $\$ 137,888$ & $\$ 12,766$ & $\$ 367,742$ & $-\$ 19,757$ & $\$ 3,910$ \\
\hline
\end{tabular}


Table 4 Mean stochastic KOVs of representative wine grape vineyards, 2015-2024 (continued)

\begin{tabular}{|c|c|c|c|c|c|}
\hline & $T X 50 a c$. & $T X 100 a c$. & $W A$ & OR & $N Y$ \\
\hline \multicolumn{6}{|l|}{ Ending cash reserves } \\
\hline 2015 & $\$ 101,239$ & $\$ 91,751$ & $\$ 334,453$ & $\$ 2,200$ & $\$ 48,582$ \\
\hline 2016 & $\$ 175,953$ & $\$ 133,086$ & $\$ 611,983$ & $\$ 1,582$ & $\$ 75,601$ \\
\hline 2017 & $\$ 244,003$ & $\$ 157,659$ & $\$ 900,605$ & $\$ 1,156$ & $\$ 91,460$ \\
\hline 2018 & $\$ 305,406$ & $\$ 173,548$ & $\$ 1,162,100$ & $\$ 1,085$ & $\$ 98,039$ \\
\hline 2019 & $\$ 346,430$ & $\$ 164,759$ & $\$ 1,350,029$ & $\$ 783$ & $\$ 96,357$ \\
\hline 2020 & $\$ 387,684$ & $\$ 166,902$ & $\$ 1,587,595$ & $\$ 1,412$ & $\$ 104,281$ \\
\hline 2021 & $\$ 410,662$ & $\$ 159,749$ & $\$ 1,774,630$ & $\$ 2,017$ & $\$ 103,318$ \\
\hline 2022 & $\$ 420,352$ & $\$ 136,225$ & $\$ 1,906,141$ & $\$ 2,689$ & $\$ 90,488$ \\
\hline 2023 & $\$ 415,260$ & $\$ 105,617$ & $\$ 2,019,962$ & $\$ 2,662$ & $\$ 73,681$ \\
\hline 2024 & $\$ 401,929$ & $\$ 76,116$ & $\$ 2,101,085$ & $\$ 3,101$ & $\$ 52,573$ \\
\hline 2015-2024 Average & $\$ 320,892$ & $\$ 136,541$ & $\$ 1,374,858$ & $\$ 1,869$ & $\$ 83,438$ \\
\hline \multicolumn{6}{|l|}{ Short-term carryover debt } \\
\hline 2015 & $\$ 15,991$ & $\$ 54,575$ & $\$ 21,725$ & $\$ 17,953$ & $\$ 24,524$ \\
\hline 2016 & $\$ 12,972$ & $\$ 73,056$ & $\$ 12,172$ & $\$ 33,460$ & $\$ 35,091$ \\
\hline 2017 & $\$ 12,153$ & $\$ 90,452$ & $\$ 6,524$ & $\$ 49,543$ & $\$ 42,979$ \\
\hline 2018 & $\$ 14,729$ & $\$ 116,249$ & $\$ 5,021$ & $\$ 66,523$ & $\$ 50,433$ \\
\hline 2019 & $\$ 15,853$ & $\$ 146,657$ & $\$ 4,716$ & $\$ 84,162$ & $\$ 62,550$ \\
\hline 2020 & $\$ 15,463$ & $\$ 178,809$ & $\$ 2,495$ & $\$ 88,735$ & $\$ 72,030$ \\
\hline 2021 & $\$ 15,960$ & $\$ 227,927$ & $\$ 1,999$ & $\$ 93,262$ & $\$ 87,641$ \\
\hline 2022 & $\$ 23,928$ & $\$ 291,667$ & $\$ 2,114$ & $\$ 103,054$ & $\$ 110,524$ \\
\hline 2023 & $\$ 27,731$ & $\$ 371,210$ & $\$ 3,131$ & $\$ 112,603$ & $\$ 144,893$ \\
\hline 2024 & $\$ 37,165$ & $\$ 477,079$ & $\$ 3,817$ & $\$ 124,560$ & $\$ 187,067$ \\
\hline 2015-2024 average & $\$ 19,194$ & $\$ 202,768$ & $\$ 6,371$ & $\$ 77,386$ & $\$ 81,773$ \\
\hline \multicolumn{6}{|l|}{ Real net worth } \\
\hline 2015 & $\$ 251,529$ & $\$ 359,785$ & $\$ 1,192,525$ & $\$ 105,456$ & $\$ 129,178$ \\
\hline 2016 & $\$ 320,436$ & $\$ 374,977$ & $\$ 1,444,858$ & $\$ 86,828$ & $\$ 145,418$ \\
\hline 2017 & $\$ 389,792$ & $\$ 399,634$ & $\$ 1,755,283$ & $\$ 78,631$ & $\$ 171,954$ \\
\hline 2018 & $\$ 448,471$ & $\$ 410,817$ & $\$ 2,025,759$ & $\$ 71,435$ & $\$ 190,911$ \\
\hline 2019 & $\$ 488,570$ & $\$ 398,426$ & $\$ 2,215,756$ & $\$ 64,827$ & $\$ 198,911$ \\
\hline 2020 & $\$ 516,475$ & $\$ 365,413$ & $\$ 2,363,174$ & $\$ 61,054$ & $\$ 194,993$ \\
\hline 2021 & $\$ 540,283$ & $\$ 325,584$ & $\$ 2,504,151$ & $\$ 58,645$ & $\$ 189,450$ \\
\hline 2022 & $\$ 554,539$ & $\$ 268,814$ & $\$ 2,628,446$ & $\$ 57,174$ & $\$ 175,329$ \\
\hline 2023 & $\$ 555,409$ & $\$ 193,453$ & $\$ 2,701,624$ & $\$ 53,124$ & $\$ 148,496$ \\
\hline 2024 & $\$ 551,252$ & $\$ 108,745$ & $\$ 2,760,226$ & $\$ 50,020$ & $\$ 117,412$ \\
\hline 2015-2024 average & $\$ 461,676$ & $\$ 320,565$ & $\$ 2,159,180$ & $\$ 68,719$ & $\$ 166,205$ \\
\hline Beginning real net worth & $\$ 213,221$ & $\$ 295,106$ & $\$ 1,057,295$ & $\$ 83,905$ & $\$ 90,683$ \\
\hline$\%$ change & $116.52 \%$ & $8.63 \%$ & $104.22 \%$ & $-18.10 \%$ & $83.28 \%$ \\
\hline
\end{tabular}

While the mean results for the KOVs in Tables 3 and 4 are useful in providing some perspective on the economic viability of the representative vineyards, Figures 1 to 5 provide more insight by focusing on the risk around the means. Figures 1 to 5 present the range of NCVI and the probability of having a cash flow deficit each year. The 
simulation results for NCVI, plotted against the left y-axis, are represented by percentiles in a fan graph format. For example, $95 \%$ of the simulated results for NCVI are equal to or below the 95th percentile line. The 75th (green) and 25th (blue) percentile lines provide a $50 \%$ range of variability around the mean, while the 95th (maroon) and 5th (red) percentile lines provide a $90 \%$ range of variability around the mean. The probability of having a cash flow deficit, and incurring short-term carryover debt, is plotted against the right y-axis.

Figure 1 TX 50 ac. representative vineyard (see online version for colours)

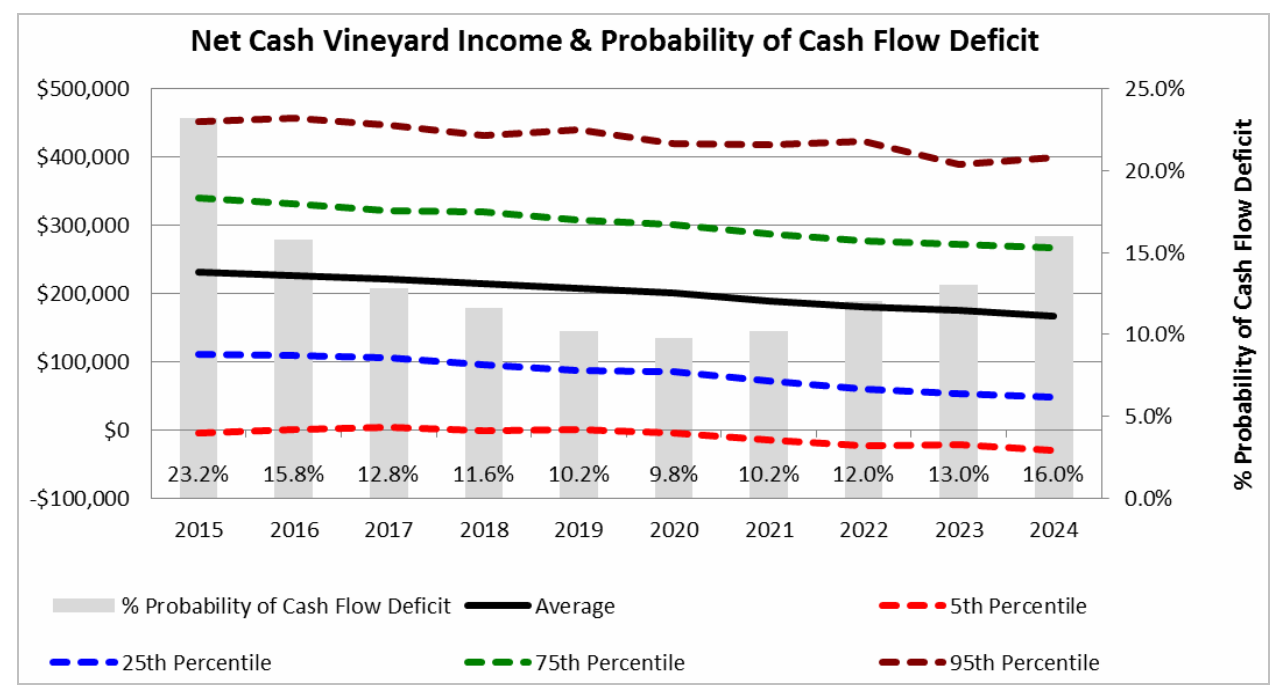

Figure 2 TX 100 ac. representative vineyard (see online version for colours)

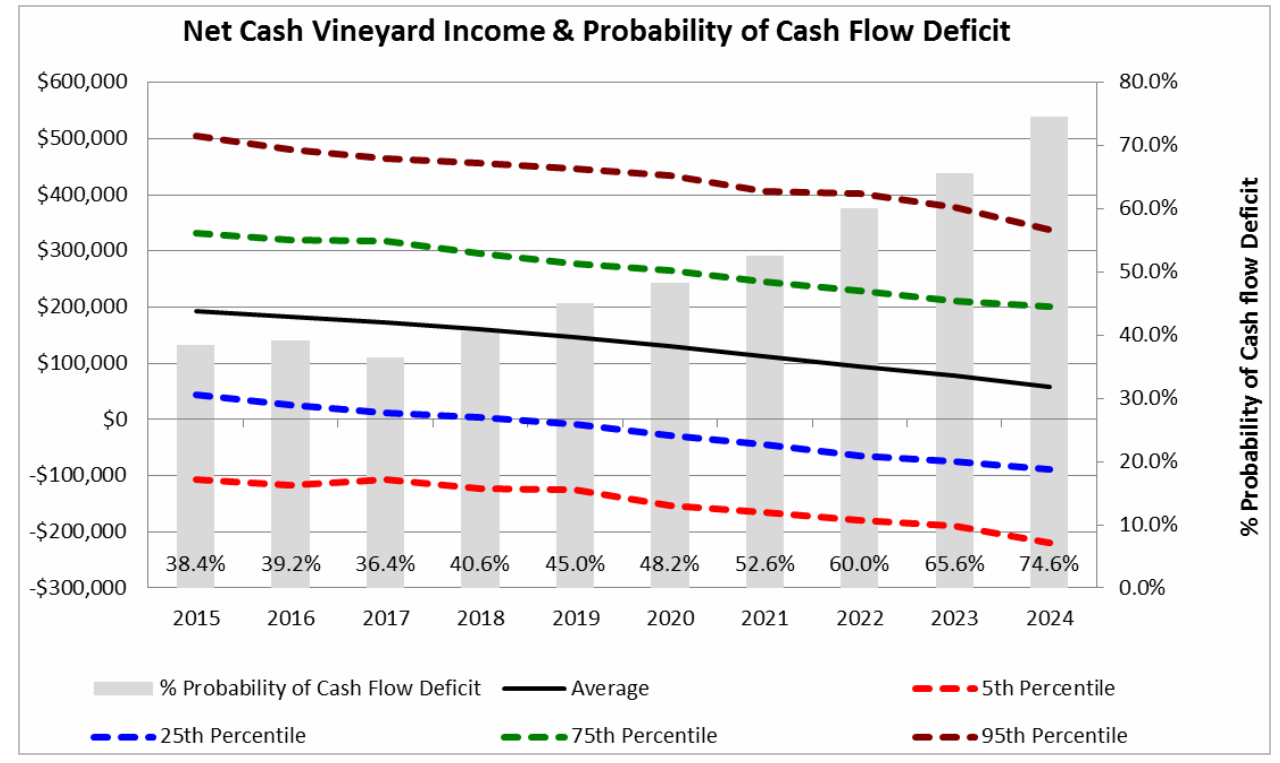


Figure 3 Washington representative vineyard (see online version for colours)

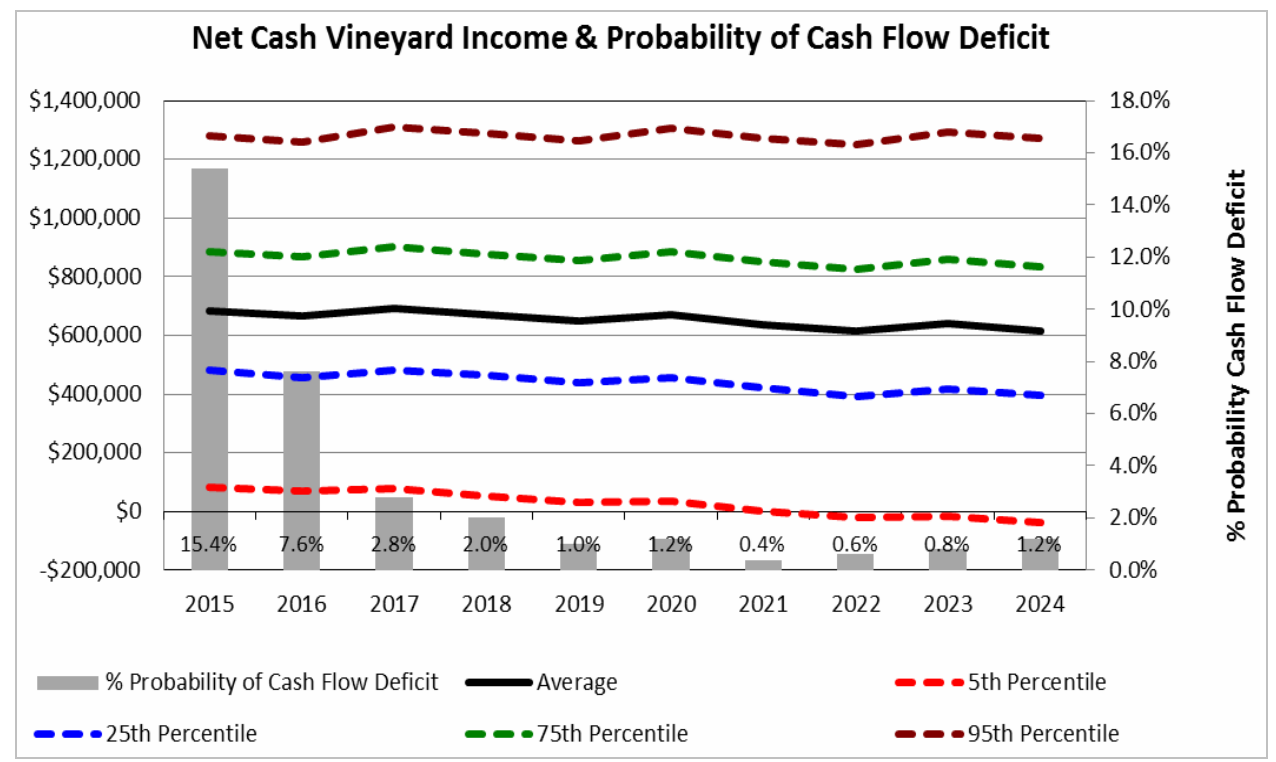

Figure 4 Oregon representative vineyard (see online version for colours)

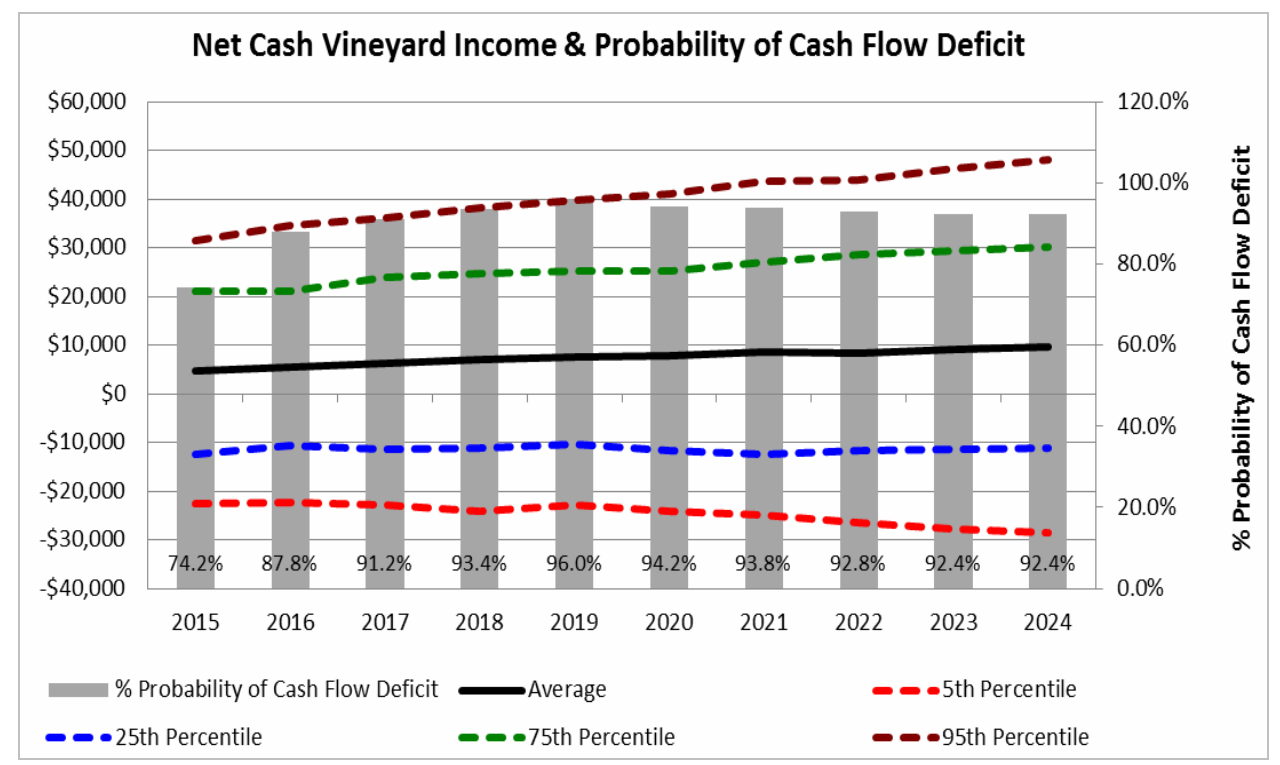


Figure 5 New York representative vineyard (see online version for colours)

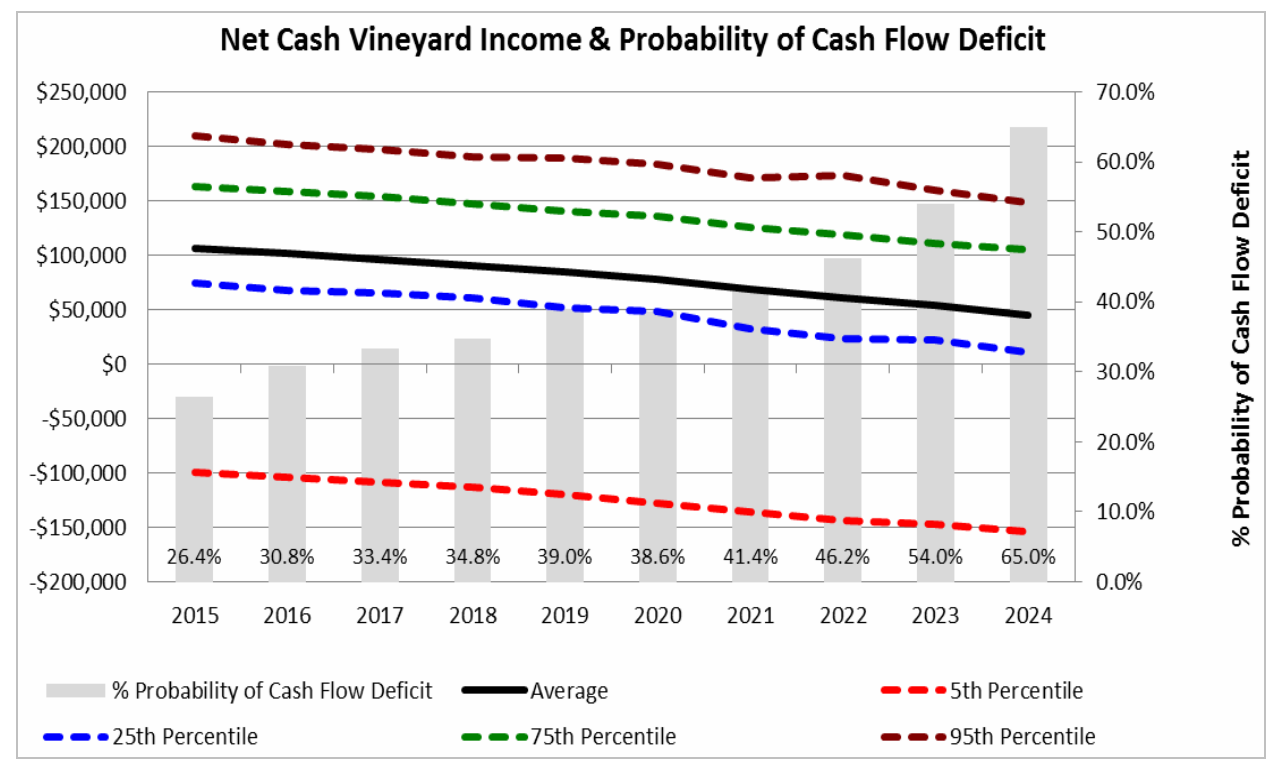

Following the work of Richardson et al. (2015), the representative vineyards are considered to be in good financial position if their probability of having a cash flows deficit is less than $25 \%$. Vineyards are considered to be in marginal financial position if the probability is between $25 \%$ and $50 \%$, and poor financial position if the probability is greater than $50 \%$.

The probability of the Texas 50 acre vineyard (Figure 1) having a cash flow deficit ranges between $9.8 \%$ and $23.2 \%$ over the ten-year planning horizon, and indicates the vineyard is in good financial condition. For the Texas 100 acre vineyard (Figure 2), NCVI declines over the ten-year planning horizon while the probability of having a cash flow deficit is on an increasing trend, ranging from $36.4 \%$ to $74.6 \%$ and is greater than $50 \%$ the last 4 years. This vineyard is in marginal to poor financial condition. The most significant factor leading to the vast differences in the results of the two Texas vineyards is yield. As explained in the Data and Methods section, the deterministic yields for the 50 and 100 acre Texas vineyards are 6.0 and 4.0 tons per acre, respectively. For the 50 acre vineyard, the increased revenue more than offsets the higher production costs (Table 2). The 100 acre vineyard does not generate enough cash flow to support its production expenses and debt service.

NCVI for the Oregon vineyard (Figure 3) is relatively flat over the ten-year planning horizon but is not at a level to cash flow the vineyard. The probability of having a cash flow deficit ranges between $74.2 \%$ and $96 \%$, placing the Oregon vineyard in poor financial condition. The financial challenges for the Oregon vineyard stem from several factors. Oregon has the most labour intensive production system of any of the five 
vineyards with a labour cost of $\$ 3,953$ per acre. The next highest labour cost is New York at $\$ 1,990$ per acre. While the Oregon vineyard is producing a premium wine, its yield of 3.0 tons per acre and price of $\$ 2,600$ per ton is not enough to support the labour, other production expenses, and debt service. The size of the Oregon vineyard, 10 acres, also makes it difficult to support its overhead costs. The panel members agreed with this assessment during the follow-up meeting with investigators, and indicated the vineyard needs assistance from the winery to make the operation viable.

With 250 acres, Washington is the largest of the five vineyards in this study. As such, it can spread its overhead costs over more acres. The vineyard also has the lowest cash costs $(\$ 3,065)$ and total costs $(\$ 5,696)$ per acre (Table 2$)$. Its production ability and price are at levels that generate a strong cash flow relative to its cost structure. Washington (Figure 4) generates a mean NCVI in the $\$ 600,000$ to $\$ 700,000$ range with variability around the mean ranging from slightly below zero on the low side, to $\$ 1.3$ million on the high side. The probability of incurring a cash flow deficit is $15.4 \%$ or less each year, putting this vineyard in good financial condition.

At $\$ 1,990$ per acre, New York has the second highest labour costs. New York also has the highest chemical and pest control costs at $\$ 800$ per acre (Table 2). The deterministic grape prices is $\$ 1,550$ per ton, which is the lowest among the five vineyards in this study (three vineyards have a deterministic price of $\$ 1,600$ per ton). These are contributing factors to the vineyard having difficulty generating enough income to support the cost structure, and service its debt. NCVI for New York (Figure 5) is on a declining trend while the probability of having a cash flow deficit is increasing. The probability is $26.4 \%$ in 2015 , and climbs each year but remains below $50 \%$ during the first 8 years. During the last two years, the probability climbs to $54 \%$ and $65 \%$, respectively. This vineyard is classified as being in marginal financial condition, but it is at risk of being in poor financial condition.

\subsection{Wine grape vineyard labour requirements and cost}

In order to assess production tasks that may lend themselves to robotic technology development, labour usage and costs for each task was provided by the vineyard panels. Production tasks are performed by both field labour and equipment operator labour (primarily tractor drivers). The research team has developed a preliminary list of production tasks that have the potential for robotic technology. These tasks are grouped into several vineyard production task categories and are presented in terms of labour hours in Table 5 and labour costs in Table 6 . Washington, which relies on less labour than the other vineyards, has the lowest labour usage per acre (114.50) and labour cost per acre (\$997.60), while Oregon has the highest labour usage per acre (250.5) and labour cost per acre $(\$ 3,953.00)$. There appear to be substantial potential labour savings from applying robotic technology to pruning and canopy management. Equipment operator hours are included in each category in Tables 5 and 6 . Considering the idea that unmanned tractors could potentially be new technology for vineyards, equipment operator hours - per acre and total for the vineyard - were summed and reported at the bottom of Table 5 while the associated costs is reported at the bottom of Table 6. For those vineyards that rely more on mechanisation, like Washington, equipment operator hours and costs are a significant portion of total labour costs. 
Table 5 Equipment operator and field labour hours by production task category for potential robotic technology development (2015)

\begin{tabular}{lccccc}
\hline & $T X 50 \mathrm{ac}$. & $T X 100 \mathrm{ac}$. & $W A$ & OR & NY \\
\hline Floor management - Dormant season & 0.60 & 0.60 & 1.20 & 0.00 & 5.00 \\
Pruning & 54.00 & 49.00 & 18.50 & 57.50 & 62.17 \\
Canopy management & 42.10 & 42.10 & 22.00 & 136.50 & 48.15 \\
Floor management - Growing season & 1.80 & 1.80 & 2.10 & 6.50 & 0.70 \\
Weed management - Vine row & 24.20 & 8.20 & 23.40 & 2.00 & 3.00 \\
Irrigation & 0.00 & 0.00 & 10.00 & 4.00 & 0.00 \\
Chemical/Pest control & 1.80 & 1.80 & 3.50 & 20.00 & 2.90 \\
Harvest & 11.00 & 11.00 & 2.00 & 24.00 & 22.50 \\
Total labour hours per acre & 135.50 & 114.50 & 82.70 & 250.50 & 144.42 \\
Total vineyard acres & 50 & 100 & 250 & 10 & 50 \\
Total labour hours $_{\text {Equipment operator hours per acre }}{ }^{1}$ & 6,775 & 11,450 & 20,675 & 2,505 & 7,221 \\
Equipment operator vineyard labour $_{\text {hours }}$ & 23.5 & 23.5 & 29.3 & 22.5 & 17.05 \\
\hline
\end{tabular}

Notes: ${ }^{1}$ Equipment operator labour hours are not in addition to total vineyard labour hours (it is included in total vineyard labour hours).

${ }^{2}$ For Oregon, all floor management practices occur during the growing season.

Table 6 Equipment operator and field labour costs by production task category for potential

\begin{tabular}{lccccc}
\hline & $T X 50 a c$. & $T X 100 a c$. & $W A$ & $O R$ & $N Y$ \\
\hline $\begin{array}{l}\text { Floor management - Dormant } \\
\text { season }\end{array}$ & $\$ 12.25$ & $\$ 12.25$ & $\$ 16.80$ & $\$ 0.00$ & $\$ 92.50$ \\
Pruning & $\$ 707.13$ & $\$ 648.98$ & $\$ 206.50$ & $\$ 883.00$ & $\$ 837.69$ \\
Canopy management & $\$ 499.29$ & $\$ 499.29$ & $\$ 248.00$ & $\$ 1,923.00$ & $\$ 637.99$ \\
$\begin{array}{l}\text { Floor management - Growing } \\
\text { season }\end{array}$ & $\$ 36.75$ & $\$ 36.75$ & $\$ 29.40$ & $\$ 117.00$ & $\$ 12.95$ \\
Weed management - Vine row & $\$ 318.36$ & $\$ 132.28$ & $\$ 312.90$ & $\$ 28.00$ & $\$ 55.50$ \\
$\begin{array}{l}\text { Irrigation } \\
\text { Chemical/Pest control }\end{array}$ & $\$ 0.00$ & $\$ 0.00$ & $\$ 110.00$ & $\$ 56.00$ & $\$ 0.00$ \\
$\begin{array}{l}\text { Harvest } \\
\text { Total labour costs per acre }\end{array}$ & $\$ 1,78.76$ & $\$ 36.76$ & $\$ 49.00$ & $\$ 316.00$ & $\$ 53.67$ \\
$\begin{array}{l}\text { Total vineyard acres } \\
\text { Total labour costs }\end{array}$ & 50 & $\$ 17.538 .19$ & $\$ 997.60$ & $\$ 3,953.00$ & $\$ 1,990.30$ \\
$\begin{array}{l}\text { Equipment operator labour } \\
\text { cost per acre }\end{array}$ & $\$ 89,121.00$ & $\$ 153,819.00$ & $\$ 249,400.00$ & $\$ 39,530.00$ & $\$ 99,515.00$ \\
$\begin{array}{l}\text { Equipment operator labour } \\
\text { costs }\end{array}$ & $\$ 23,993$ & $\$ 47,986$ & $\$ 102,550$ & $\$ 3,950$ & $\$ 15,773$ \\
\hline
\end{tabular}

Notes: ${ }^{1}$ Equipment operator labour costs are not in addition to total vineyard labour hours (it is included in total labour costs).

${ }^{2}$ For Oregon, all floor management practices occur during the growing season.

Source: Robotic Technology Development (2015) 
Table 7 NPV per acre for selected vineyard practices for precision mechanisation

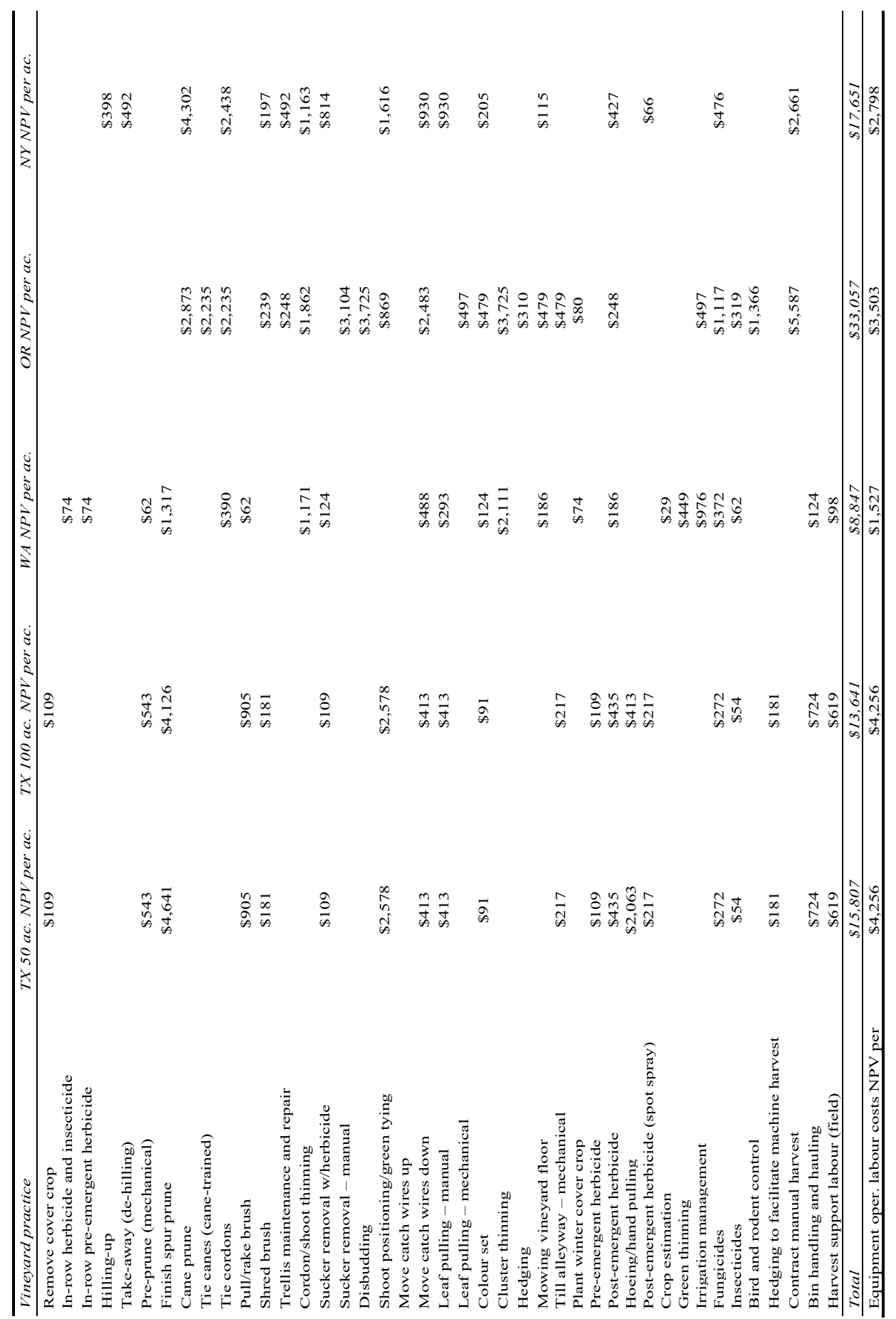


If new technology can be developed and made available commercially to growers, it would most likely carry a price that would necessitate a capital purchase whereby a grower would secure a loan, incur annual payments and interest cost, and the technology would be depreciated over several years. These types of decisions are usually evaluated using net present value (NPV) to compare the NPV of the cash outflows for using manual labour to the NPV of the cash outflows associated with purchasing new technology. To provide some insight into the NPV of projected labour costs for each production task (not categories) that could offer the potential for new technology; the ten-year projected labour costs for each task were discounted at a 5\% discount rate. The resulting NPVs per acre for each task are presented in Table 7 which shows significant variation depending on the task, and representative vineyard. In general, the tasks with highest NPVs are finish spur pruning, cane pruning, tie canes, tie cordons, shoot positioning/green, and contract manual harvest.

\section{Summary and conclusions}

Representative wine grape grower panels in four states provided important input regarding wine grape production costs in their respective regions and production tasks that have potential to be automated with robotic technology. Under current production tasks and technology, Monte Carlo simulation model results indicate that two of the vineyards are in good financial condition, one is in marginal-to-poor financial condition, one is in marginal condition but is at risk of being in poor condition, and one is in poor condition. These results are an indication that most of the growing areas are in need of improved financial conditions that could potentially come from new technology.

Equipment operator and field labour usage and cost data provided by the grower panels show a wide range across the representative vineyards with labour hours per acre ranging from 82.70 to 250.50 , and labour costs ranging from $\$ 997.60$ to $\$ 3,953.00$ per acre. Equipment operator labour and costs alone is also significant, especially for those vineyards that rely more on mechanisation. The NPV of labour costs over ten years was presented for production tasks that may be conducive for robotic technology. For a producer of premium wine grapes, eight production tasks have a NPV of more than $\$ 2,000$, ranging from $\$ 2,235$ for tying canes to $\$ 5,587$ for manual (hand) harvest. This analysis provides important insight for technology developers in identifying and prioritising the production tasks to focus on for new technology development, and for determining a price range to facilitate adoption by wine grape growers.

\section{Acknowledgements}

The project was supported by the Agricultural and Food Research Initiative Competitive Program of the US Department of Agriculture - National Institute of Food and Agriculture (NIFA), Grant No. 2014-68006-21841. 


\section{References}

Agricultural and Food Policy Centre, Department of Agricultural Economics, Texas A\&M University [online] https://www.afpc.tamu.edu (accessed 8 December 2015).

Daugovish, O., Klonsky, K.M. and De Moura, R.L. (2011) Sample Costs to Produce Strawberries: South Coast Region - Ventura County, Oxnard Plain, ST-SC-11-2, University of California Cooperative Extension.

Falconer, L.L. and Richardson, J.W. (2013) 'Economic analysis of crop insurance alternatives under surface water curtailment uncertainty', Selected paper presented at the Southern Agricultural Economics Association (SAEA) Annual Meeting, 3-5 February 2013, Orlando, FL.

Food and Agricultural Policy Research Institute (FAPRI) (2015) US Baseline Briefing Book: Projections for Agricultural and Biofuel Markets, FAPRI-MU Report \#01-15, March, University of Missouri, Columbia, MO.

Hardaker, J.B., Huirne, R.B.M., Anderson, J.R. and Lien, G. (2004) Coping with Risk in Agriculture, CABI Publishing, Wallingford, Oxfordshire, UK.

Julian, J.W., Strik, B.C. and Yan, W. (2011) Blueberry Economics: The Costs of Establishing and Producing Blueberries in the Willamette Valley, AEB 0022, April, Oregon State University Extension Service.

Menghi, A., de Roest, K., Porcelluzzi, A., Deblitz, C., von Davier, Z., Wildegger, B., de Witte, T., Strohm, K., Garming, H., Dirksmeyer, W., Zimmer, Y. and Bölling, D. (2011) Assessing Farmers' Costs of Compliance with EU Legislation in the Fields of Environment, Animal Welfare, and Food Safety, AGRI-2011-EVAL-08, Commissioned by the European Commission Directorate-General for Agriculture and Rural Development.

MKF Research (2007) The Impact of Wine, Grapes and Grape Products on the American Economy 2007: Family Business Building Value, MKF Research LLC, Helena, CA.

National Agricultural Statistics Service (NASS) (215) United States Department of Agriculture [online] https://www.nass.usda.gov/Statistics_by_State/ (accessed 24 February 2017).

Outlaw, J.L., Ribera, L.A., Richardson, J.W., Silva, J., Bryant, H. and Klose, S.L. (2007) 'Economics of sugar-based ethanol production and related policy issues', Journal of Agricultural and Applied Economics, August, Vol. 39, No. 2, pp.357-363.

Paggi, M.S., Yamazaki, F. and Qiao, F. (2007) Specialty Crop Representative Farm Models: Forecasts, Policy Analysis and International Comparative Studies, Final Report: Representative Farm Model Specialty Crop Policy Study, The California Institute for the Study of Specialty Crops, College of Agriculture, Food and Environmental Sciences, California Polytechnic State University, San Luis Obispo, CA.

Plastina, A. (2016) Estimated Costs of Crop Production in Iowa - 2016, Ag Decision Maker, FM 1712, January, Iowa State University Extension and Outreach.

Pouliquen, L.Y. (1970) Risk Analysis in Project Appraisal, World Bank Staff Occasional papers No. 11, International Bank for reconstruction and Development, The John Hopkins University Press.

Reutlinger, S. (1970) Techniques for Project Appraisal Under Uncertainty, World Bank Staff Occasional papers No. 10, International Bank for reconstruction and Development, The John Hopkins University Press.

Richardson, J.W. (2006) Simulation for Applied Risk Management, Unnumbered Staff Report, Department of Agricultural Economics, Agricultural and Food Policy Centre, Texas A\&M University, College Station, Texas.

Richardson, J.W. and Mapp Jr., H.P. (1976) 'Use of probabilistic cash flows in analyzing investments under conditions of risk and uncertainty', Southern Journal of Agricultural Economics, December, Vol. 8, No. 2, pp.19-24. 
Richardson, J.W., Herbst, B.K., Outlaw, J.L. and Gill II, R.C. (2007) 'Including Risk in economic feasibility analyses: the case of ethanol production in Texas', Journal of Agribusiness, Fall, Vol. 25, No. 2, pp.115-132.

Richardson, J.W., Outlaw, J.L., Knapek, G.M., Raulston, J.M., Herbst, B.K., Anderson, D.P. and Klose, S.L. (2015) Representative Farms Economic Outlook for the December 2015 FAPRI/AFPC Baseline, Briefing paper 15-3, December 2015, Agricultural and Food Policy Centre, Department of Agricultural Economics, Texas A\&M University, College Station, Texas.

Smith, J. (2015) 2015 Estimated Costs and Returns Per Acre, Dryland Wheat, South Plains extension District 2, Texas A\&M AgriLife Extension Service, Department of Agricultural Economics, The Texas A\&M University System.

The National Association of American Wineries (2014) [online] http://wineamerica.org/policy/bythe-numbers (accessed 9 December 2015).

\section{Notes}

1 Given irrigation limitations in the Texas South Plains, the 50 acre Texas representative vineyard owns 150 acres; 50 acres is in wine grapes and 4 acres consists of buildings, roads, etc. The remaining 96 acres is rented out for dryland crop production at $\$ 30$ per acre which equates to $\$ 57.60$ in rental income per 50 acres of wine grapes. The 100 acre representative vineyard has the same arrangement.

\section{Appendix}

Equations for simulation model for wine grape production in the USA

Stochastic variables

$$
\begin{aligned}
& \text { Grape Price }_{t}=\text { Mean Price }_{t} \times\left[1+\operatorname{Empirical}\left(S_{i}, F\left(S_{i}\right)\right]\right. \\
& \text { Grape Yield }_{t}=\text { Mean Yield } t \times\left[1+\operatorname{Empirical}\left(R_{i}, F\left(R_{i}\right)\right]\right.
\end{aligned}
$$

\section{Income}

Wine Grape Sales ${ }_{t}=$ Grape Price $_{t} \times$ Grape Yield $_{t} \times$ Number of acres

Crop insurance indemnity paymentt

$=\left(\right.$ Guaranteed Yield $_{t}-$ Grape Yield $\left._{t}\right) \times$ Established

Price [When grape yield is less than the guaranteed yield]

$\times$ Number of acres

Land Rental Income ${ }_{t}=$ Number of acres $\times$ Rate per acre for land rental

Total Income I $_{t}=$ Wine Grape Sales $_{t}+$ Crop Insurance Indemnity Payment ${ }_{t}$ + Land Rental Income I $_{\text {}}$ 


\section{Expenses}

$$
\begin{aligned}
& \text { Fertiliser } \text { Cost }_{t}=\text { Fertiliser Cost }_{t-1} \times\left(1+\text { Inflation Rate }_{t}\right) \\
& \times \text { Number of acres } \\
& \text { Fungicide Cost } \text { Fungicide Cost }_{t-1} \times\left(1+{\text { Inflation } \left.\text { Rate }_{t}\right)}\right. \\
& \times \text { Number of acres } \\
& \text { Insecticide Cost }_{t}=\text { Insecticide Cost }_{t-1} \times\left(1+\text { Inflation Rate }_{t}\right) \\
& \times \text { Number of acres }
\end{aligned}
$$

Tying Material Cost C $_{t}=$ Tying Material Cost C $_{t-1} \times\left(1+\right.$ Inflation Rate $\left._{t}\right)$ $\times$ Number of acres

Soil Sampling Cost $_{t}=$ Soil Sampling Cost t $_{t-1} \times\left(1+\right.$ Inflation Rate $\left._{t}\right)$

$\times$ Number of acres

Trellis Repair Cost $t_{t}=$ Trellis Repair Cost $t_{t-1} \times\left(1+{\left.\text { Inflation } \text { Rate }_{t}\right)}\right.$ $\times$ Number of acres

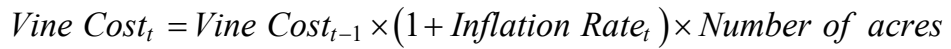

Rodent Control Cost $t_{t}=$ Rodent Control Cost $t_{t-1} \times\left(1+\right.$ Inflation Rate $\left._{t}\right)$ $\times$ Number of acres

Propane Cost $_{t}=$ Propane $_{\text {Cost }}+1 \times\left(1+\right.$ Inflation Rate $\left._{t}\right)$

$\times$ Number of acres

Seed Cost $_{t}=$ Seed Cost $_{t-1} \times\left(1+{\left.\text { Inflation } \text { Rate }_{t}\right) \times \text { Number of acres }}\right.$

Irrigation Cost Irrigation Cost $_{t-1} \times\left(1+{\left.\text { Inflation } \text { Rate }_{t}\right)}\right.$

$\times$ Number of acres

Custom Contract Cost $t_{t}=$ Custom Contract Cost $t_{t-1}$

$$
\times\left(1+\text { Inflation } \text { Rate }_{t}\right) \times \text { Number of acres }
$$

Machinery Labour Cost $t_{t}=$ Machinery Labour Cost $_{t-1}$

$$
\times\left(1+{\text { Inflation } \left.\text { Rate }_{t}\right) \times \text { Number of acres }}\right.
$$

Non-machinery Labour Cost $t_{t}=$ Non-machinery Labour Cost L $_{t-1}$

$$
\times\left(1+\text { Inflation Rate }_{t}\right) \times \text { Number of acres }
$$

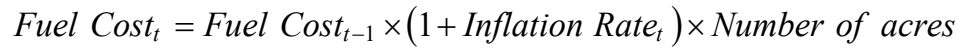


Lube Cost $_{t}=$ Lube Cost $_{t-1} \times\left(1+\right.$ Inflation Rate $\left._{t}\right) \times$ Number of acres

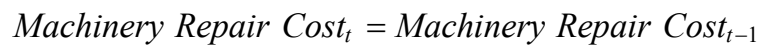

$$
\times\left(1+\text { Inflation } \text { Rate }_{t}\right) \times \text { Number of acres }
$$

Buildings and tools maintenance and Repair Cost

$=$ Buildings and tools maintenance and Repair Cost $t_{t-1}$

$\times\left(1+\right.$ Inflation Rate $\left._{t}\right) \times$ Number of acres

Management Cost $_{t}=$ Management Cost $_{t-1}$

$$
\times\left(1+{\text { Inflation } \left.\text { Rate }_{t}\right) \times \text { Number of acres }}\right.
$$

Crop Insurance Cost $t_{t}=$ Crop Insurance Cost I $_{t-1}$

$$
\times\left(1+{\text { Inflation } \left.\text { Rate }_{t}\right) \times \text { Number of acres }}\right.
$$

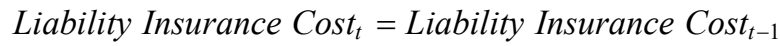

$$
\times\left(1+{\text { Inflation } \left.\text { Rate }_{t}\right) \times \text { Number of acres }}\right.
$$

Property Insurance Cost $t_{t}=$ Property Insurance Cost $_{t-1}$

$$
\times\left(1+{\text { Inflation } \left.\text { Rate }_{t}\right) \times \text { Number of acres }}\right.
$$

Property Taxes Cost $t_{t}=$ Property Taxes Cost $_{t-1}$

$$
\times\left(1+\text { Inflation } \text { Rate }_{t}\right) \times \text { Number of acres }
$$

Office Cost $_{t}=$ Office Cost $t_{t-1} \times\left(1+\right.$ Inflation Rate $\left._{t}\right) \times$ Number of acres

Operating Interest $_{t}=$ Total Variable Cost $_{t} \times$ OP Interest Rate $_{t}$

$\times$ Fraction of year $\times$ Number of acres

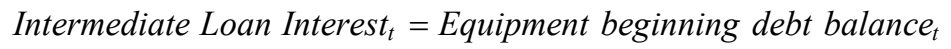

$$
\times \text { Fixed Interest } \text { Rate }_{t}
$$

Long-term Loan Interest

$=$ Land, Buildings, and Drip Irrigation System Beginning Debt Balance ${ }_{t}$

$\times$ Fixed Interest Rate $_{t}$

Establishment Costs Loan Interest $t_{t}$

= Vineyard Establishment Costs Beginning Debt Balance ${ }_{t}$

$\times$ Fixed Interest Rate

Total Interest Cost $_{t}=$ Operating Interest I $_{t}+$ Intermediate Loan Interest $_{t}$

+ Long-term Interest $t_{t}$

+ Establishment Cost Loan Interest $t_{t}$ 
${\text { Equipment } \text { Depreciation }_{t}=\left(\text { Equipment }_{\text {Cost }} \times M A C R S_{t}\right.}$

+ Capital Replacement $\left.\times M A C R S_{t}\right)$

$\times$ Number of acres

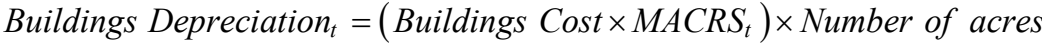

Drip Irrigation Depreciation $_{t}=\left({\left.\text { Drip Irrigation System Cost } \times M A C R S_{t}\right)}\right)$

$\times$ Number of acres

Establishment Costs Depreciation ${ }_{t}=\left({\text { Establishment Costs } \times M A C R S_{t}}\right.$

+ Capital Replacement $\times M A C R S_{t}$ )

$\times$ Number of acres

Total Depreciation $_{t}=$ Equipment $_{\text {Depreciation }}+$ Buildings $_{t}$ Depreciation $_{t}$

+ Drip Irrigation System Depreciation

+Establishment Costs Depreciation

Net Cash Vineyard Income I $_{t}=$ Total Income I $_{t}-$ Total Variable Costs $_{t}$

-Total Interest Cost

Net Cash Vineyard Income I $_{t}=$ Total Income I $_{t}-$ Total Variable Costs $_{t}$

$$
\text { -Total Interest } \text { Cost }_{t}
$$

Net Vineyard Income $_{t}=$ Total Income I $_{t}-$ Total Expenses $_{t}$

Cash flow statement

Total Cash Available $_{t}=$ Net Cash Vineyard Income I $_{t}$

+ Positive Cash Reserves $_{t-1}$

Principal Payment Long-Term Loan ${ }_{t}=$ Fixed Annual Payment

-Long-term Loan Interest $t_{t}$

Principal Payment Intermediate Term Loan $_{t}=$ Fixed Annual Payment

-Intermediate Loan Interest ${ }_{t}$

Principal Payment Establishment Costs C $_{t}=$ Fixed Annual Payment

-Establishment Costs Loan Interest 
Carryover Loan Payment $_{t}=\left(\right.$ Beginning Debt Balance $_{t-1}$

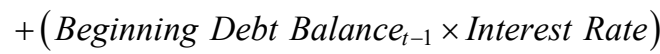

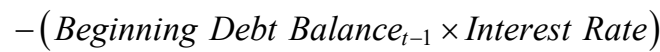

Owner Operator Management Withdrawls

$=$ Owner Operator Management Withdrawls $s_{t-1} \times\left(1+\right.$ Inflation Rate $\left._{t}\right)$

Federal Income Taxes $_{t}=$ Positive Net Vineyard Income $_{t}$

$\times$ Income Tax Rate

Self-employment and Social Security Taxes $_{t}$

$=\left(\right.$ Positive Net Vineyard Income $e_{t} \times$ Self-Employment Tax Rate $)$

$+\left(\right.$ Positive Net Vineyard Income $_{t} \times$ Medicare Tax Rate $)$

Cash Outflows ${ }_{t}=$ Cash Vineyard Expenses E $_{t}$

+ Principal Payment Long-term Loan

+Principal Payment Intermediate Term Loan

+ Principal Payment Establishment Cost $_{t}$

+ Operating Loan Carryover $_{t-1}$

+ Owner Operator Management Withdrawls

+ Federal Income Taxes $_{t}$

+ Self-employment and Social Security Taxes T $_{t}$

Ending Cash Reserves R $_{t}$ Total Cash Available $_{t}-$ Cash Outflows $_{t}$

Balance sheet

Assets $_{t}=$ Land Value + Book Value Farm Machinery

+ Positive Ending Cash $_{t}$

Liabilities $_{t}=$ Long-term Loan Debt $t_{t}+$ Intermediate Loan Debt $_{t}$ + Establishment Costs Debt $_{t}+$ Short-term Loan Debt $_{t}$

Nominal Net Worth $_{t}=$ Assets $_{t}-$ Liabilities $_{t}$

Real Net Worth $_{t}=\left(\right.$ Inflation Rate Year $1 \div$ Inflation Rate I $\left._{t}\right)$

$\times$ Nominal Net Worth $_{t}$ 
Table A1 Projected inflation rates for machinery and other farm operations

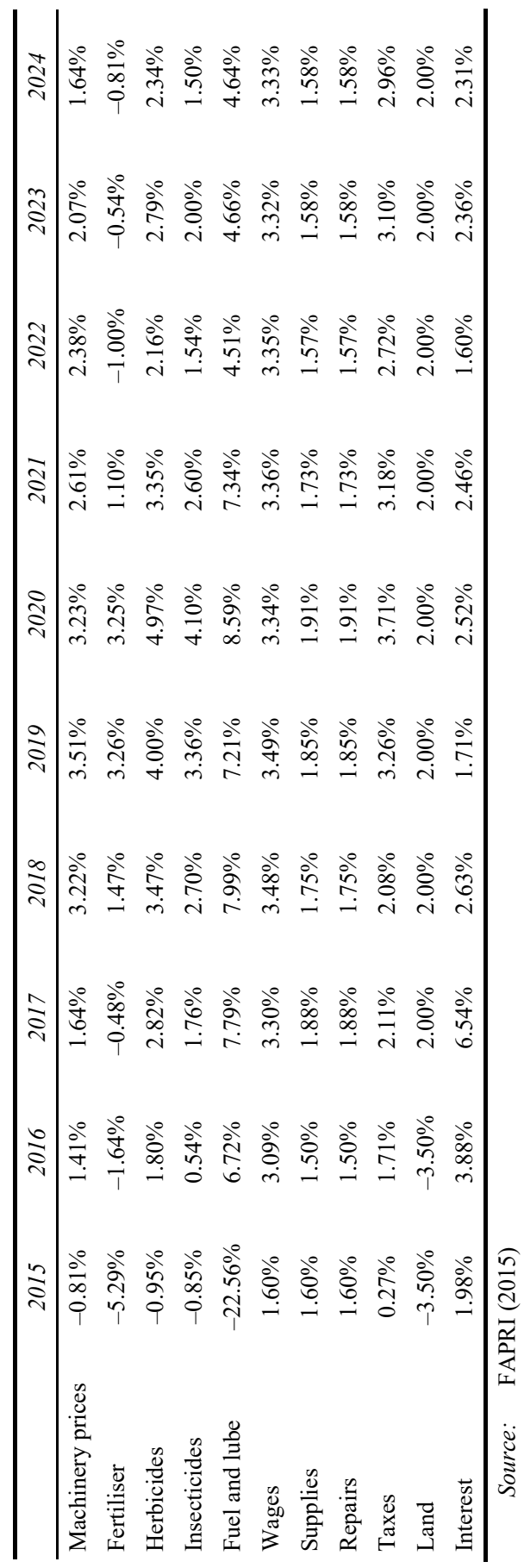

